\title{
Uma análise da dívida externa brasileira a partir dos anos 2000
}

\author{
Ricardo Lobato Torres* \\ Carolina Silvestri Cândido** \\ Adriana Ripka***
}

\begin{abstract}
Resumo
O objetivo deste artigo foi analisar a dívida externa brasileira a partir dos anos 2000, com foco na vulnerabilidade externa, custos e sustentabilidade. Realizou-se revisão da literatura sobre o tema e fez-se levantamento de dados secundários a partir das estatísticas do Banco Central do Brasil. Foram analisadas variáveis como o investimento internacional líquido, taxa de juros dos títulos públicos, taxa de câmbio, dívida líquida do setor público e custo real da dívida nãomonetária. Os resultados mostram que houve redução da vulnerabilidade externa por conta do acúmulo de reservas em moeda estrangeira e pela substituição da dívida pública externa pela interna. Contudo, permanece a condição de vulnerabilidade externa estrutural, em função da necessidade de atração de capital estrangeiro para o equilíbrio no balanço de pagamentos e, por conseguinte, do círculo vicioso gerado entre a política monetária, o resultado físcal e a redução do crescimento econômico. Houve deterioração da posição de investimento internacional do Brasil, principalmente a partir de 2015, com a desvalorização cambial, o que implica uma elevação dos riscos associados à dívida externa.
\end{abstract}

Palavras-chave: Dívida externa; Vulnerabilidade externa; Brasil.

\section{An analysis of the Brazilian external debt from the 2000s onwards}

\begin{abstract}
This article aimed to analyze the Brazilian external debt from the 2000s onwards, focusing on external vulnerability, costs and sustainability. A literature review on the subject was carried out and secondary data was collected from the statistics by the Central Bank of Brazil. Variables such as the net international investment, interest rate on public securities, exchange rate, net public sector debt and the real cost of non-monetary debt were analyzed. The results show that there was a reduction in external vulnerability due to the accumulation of reserves in foreign currency and the replacement of the external public debt by the internal one. However, the condition of structural external vulnerability remains due to the need to attract foreign capital to balance the balance of payments and, therefore, the vicious circle between monetary policy, the resulting tax and the reduction of the for economic growth. There was a deterioration in Brazil's international investment position, especially as of 2015, with exchange devaluation, which implies an increase in the risks associated with the external debt.
\end{abstract}

Keywords: External debt; External vulnerability; Brazil.

Classificação JEL: E63; H62; H63

* Economista e Doutor em Economia da Indústria e da Tecnologia (UFRJ), Professor do Departamento de Economia da Universidade Federal do Paraná (UFPR). E-mail: ricardotorres@ufpr.br.

** Economista e Doutora em Economia (UFRGS), Professora do Departamento de Gestão e Economia da Universidade Tecnológica Federal do Paraná (UTFPR). E-mail: carolinascandido@ gmail.com.

***Economista e Doutora em Tecnologia e Sociedade (UTFPR). E-mail: a_ripka@ hotmail.com. 


\section{Introdução}

Na história do Brasil não é incomum o país recorrer ao financiamento externo para a execução de programas governamentais, como o foi o caso do II Plano Nacional de Desenvolvimento, em 1973. Este, em especial, foi um dos responsáveis pelo alto endividamento externo do país, que levou o Brasil a enfrentar uma severa crise na década de 1980, pela incapacidade de pagamento da dívida.

Fatores externos como a segunda crise do petróleo em 1979 e a moratória do México, em 1982, somaram negativamente às tentativas do Brasil de alcançar novos financiamentos externo que pudessem incorrer em custos menores e, até mesmo, de efetuar o pagamento junto aos credores já existentes. No primeiro caso, a elevação dos juros internacionais acabou pressionando o balanço de pagamentos do Brasil, ao passo que o segundo desencadeou insegurança dos credores externos que, somado às dificuldades que o país já enfrentava para cumprir as exigências do Fundo Monetário Internacional (FMI), aprofundou a crise do país no período.

Internamente, o cenário político também ganha destaque ao se tratar da dívida externa, pois, a condução do cenário econômico e, consequentemente, o gerenciamento dos instrumentos fiscais e monetários acabam por impactar no montante da dívida externa de um país. No caso do Brasil, o avanço dos anos 1980 para a década de 1990, apesar de apresentar uma relativa melhora da dívida externa, comparada com o período anterior, a utilização intensiva de mecanismos de atração de capital estrangeiro levou o país a efeitos colaterais como baixa no investimento produtivo, encadeando uma série de efeitos danosos à economia interna.

Dando seguimento para os anos 2000, pode-se observar no Brasil alguns elementos como a redução da vulnerabilidade externa da economia nacional, elevação das exportações e redução da dívida líquida, que decorrem de políticas envolvendo instrumentos como, por exemplo, o mercado de câmbio. Da mesma forma que pode se verificar a presença de indicadores favoráveis em determinados períodos, como o de 2003 a 2007, pode-se observar cenários de crise em períodos como de 2015 a 2016. Mais recentemente, devido a pandemia de COVID-19, deflagrada no ano de 2020, o país se encontra em meio a uma crise da qual, os problemas ainda estão sendo desvendados, da mesma forma que as soluções ainda carecem de desenvolvimento. Frente a isso, cabe o aprofundamento da discussão envolvendo elementos historicamente críticos à economia do Brasil, como é o caso da dívida externa, bem como outros indicadores que a impactam, tais como a posição de investimento internacional líquida, taxa de 
juros SELIC, taxa de câmbio (R\$/US\$), Dívida Líquida do Setor Público (DLSP), Dívida Mobiliária Federal e custo real da dívida não-monetária total.

Nesse sentido, este artigo tem como objetivo analisar a dívida externa do Brasil a partir dos anos 2000, proporcionando uma discussão sobre a vulnerabilidade externa, os seus custos e sua sustentabilidade. Para tanto, recorreu-se ao levantamento bibliográfico, para a análise contextual dos elementos que traçaram a trajetória da dívida externa brasileira no período estudado, bem como à coleta de dados sobre a dívida externa, a partir do Sistema Gerenciador de Séries Temporais (SGS) do Banco Central do Brasil.

O presente artigo encontra-se dividido em cinco seções. Nessa primeira, realiza-se a introdução; na segunda, faz-se a revisão de literatura sobre a dívida externa brasileira; na terceira apresenta-se a metodologia utilizada; na quarta discutem-se os resultados; e por fim, a quinta realiza-se a conclusão do artigo.

\section{A dívida externa brasileira em perspectiva histórica}

As políticas econômicas do governo brasileiro, durante o período de industrialização por substituição de importações, foram fortemente baseadas em captação externa de capitais para investimento. Políticas como a indexação de ativos financeiros e o crescimento baseado no endividamento externo, de acordo com Bresser-Pereira (2017), trouxeram ao país a crise da dívida externa, estagnação econômica e alta inflação inercial. Na década de 1980, o Brasil sofreu uma de suas maiores crises econômicas do período republicano, decorrente da incapacidade de pagamento da dívida externa contraída nos anos anteriores, em especial a obtida para o financiamento do II Plano Nacional de Desenvolvimento (1973). Após o segundo choque do petróleo, em 1979, a elevação dos juros internacionais impôs fortes restrições ao balanço de pagamentos brasileiro. E, mesmo recorrendo ao FMI e a outras instituições multilaterais para obter ajuda financeira, a fim de honrar seus compromissos no exterior, aprofundou-se a crise da dívida ao longo dos anos 1980. Isso ocorreu principalmente por causa do estancamento do crédito voluntário após a moratória do México, em 1982, e pelos recorrentes incumprimentos de cláusulas estabelecidas nos acordos do governo brasileiro com o FMI. A insustentabilidade das condições impostas pelos credores internacionais, nas sucessivas negociações de financiamento da dívida, a partir de então, resultou na decretação da moratória da dívida pública brasileira em 1987. As consequências mais graves das políticas econômicas restritivas, no entanto, foram os altos custos sociais derivados da gestão da dívida nesse período: a redução dos salários reais e o aumento do desemprego (SALOMÃO, 2016). 
As aberturas comercial e financeira da economia brasileira na década de 1990, em especial após a implementação do Plano Real, significaram a introdução de um novo modelo de crescimento, baseado na poupança externa. Aliado a outras estratégias de política econômica, como a âncora cambial para o controle inflacionário, em um primeiro momento, e as elevadas taxas de juros dos títulos públicos no regime de metas de inflação, em um segundo momento, produziu-se uma sobrevalorização da moeda brasileira, o que contribuiu para a acumulação de déficits em transações correntes até 2002. A atratividade desses fatores conjunturais ao capital externo implicou em crescente endividamento, principalmente após a eclosão da crise do real no final de 1998. E, novamente, o governo brasileiro se viu obrigado a recorrer a empréstimos do FMI. Embora os impactos sobre os preços e o crescimento do PIB tenham sido negativos, em decorrência do abandono do regime de câmbio semifixo e da abrupta desvalorização do real, os efeitos foram mais brandos do que os produzidos na década anterior (BRESSER-PEREIRA; GONZALEZ; LUCINDA, 2008).

Apesar disso, houve uma financeirização da economia brasileira nesse período, que se viu apanhada em uma verdadeira armadilha, a qual aumentou significativamente a vulnerabilidade externa do país. A necessidade de constante atração de capital estrangeiro, para honrar os compromissos do balanço de pagamentos, fez com que o governo federal adotasse uma política de juros elevados e crescente emissão de títulos da dívida pública. E, em virtude das crises internacionais e outros fatores institucionais, o fluxo desses capitais se tornou cada vez mais volátil. Como resposta, o governo intensificava os mecanismos de atração já mencionados, o que contribuiu para um aumento expressivo do estoque da dívida pública federal, principalmente a partir de 1997, após a crise asiática. Como efeitos colaterais dessa estratégia do governo, houve uma abrupta queda nos investimentos produtivos, reorientação do capital acumulado para a esfera financeira e redução do crédito para financiamento empreendedor e ao consumo das famílias. Esses fatores contribuíram de maneira decisiva para o baixo crescimento da economia no período, o que revela o potencial devastador da dívida externa, nesse caso essencialmente pública, para o funcionamento da economia nacional (MEDIALDEA, 2013).

Ao longo da década de 2000, principalmente a partir de 2003, houve uma transição na composição da chamada posição internacional dos investimentos ${ }^{1}$ que reduziu a

\footnotetext{
${ }^{1}$ Até 1993, adotava-se o conceito de dívida externa líquida, que foi substituído pelo termo posição internacional dos investimentos a partir da nova metodologia da $5^{\text {a }}$ edição do Manual de Balanço de Pagamentos do Fundo Monetário Internacional, não sendo este último um correspondente perfeito do primeiro.
} 
vulnerabilidade externa da economia brasileira. O crescimento das exportações no período de 2003 a 2008 contribuiu significativamente para a geração de superávits comerciais, incorrendo em alguns períodos de saldos positivos em transações correntes. Ademais, com os influxos de capital externo, em especial, de investimento estrangeiro direto, houve acumulação de reservas internacionais. Estas superaram o passivo externo líquido, fazendo com que a dívida externa líquida se tornasse negativa a partir de 2008. Assim, por um lado, a vulnerabilidade externa se reduziu por conta da acumulação de divisas internacional, na qual as políticas de intervenção do Banco Central no mercado de câmbio foram fundamentais para esse propósito. Por outro lado, e talvez mais importante, foi a mudança na composição da dívida externa brasileira, havendo uma substituição gradativa das dívidas em moeda estrangeira por compromissos em moeda nacional. Em 2003, as dívidas em moeda estrangeira representavam 67\% do total, reduzindo-se para 36\%, em 2010 (CUNHA; PRATES; BICHARA, 2013; VAN NOIJE, 2014).

No entanto, a interpretação de que a vulnerabilidade externa brasileira tenha se reduzido por conta desses fatores não é um consenso na literatura. Alguns economistas defendem que o acúmulo de reservas e a redução do endividamento líquido externo, a partir do segundo quarto da década de 2000, camufla o risco inerente de fuga de capitais. Isso porque, em que pese a melhoria dos indicadores supracitados, permanece o levado peso de capitais financeiros de curto prazo sobre o balanço de pagamento do Brasil, os quais respondem fortemente a fatores exógenos. Além disso, o controle de capitais adotado no Brasil desde os anos 1990, baseado na cobrança de imposto sobre entrada e saída de recursos do país (Imposto sobre Operações Financeiras - IOF), mostra-se insuficiente para reverter ou amenizar os fluxos financeiros em momentos de crise. Variáveis que afetam diretamente a rentabilidade do investidor estrangeiro, como a taxa de câmbio, ou sua percepção de risco, como os indicadores de risco-país e a eclosão de crises em outras partes do mundo, explicam a maior parte das decisões de entrada e saída de recursos, principalmente em países em desenvolvimento. E, muitas vezes, essas variáveis fogem do controle da autoridade monetária nacional (MUNHOZ, 2013).

Diante do risco de saída abrupta de capital financeiro e sem conexão com os fundamentos da economia nacional, como a experimentada nas crises do México, Rússia, Ásia e mesmo a brasileira ao longo dos anos 1990, a partir da década seguinte os bancos centrais dos países de economias emergentes passaram a adotar uma estratégia de salvaguarda para os momentos de crise. Esta consistiu em intervenção ativa no mercado de câmbio para a acumulação de reservas em moeda estrangeira, especialmente o dólar, tido como a moeda mundial. Antes da crise financeira de 2008, houve um ingresso massivo de capital financeiro nessas economias, atraídos principalmente pelo diferencial das taxas de juros dos títulos 
públicos com relação às prevalecentes nos países desenvolvidos, em especial as do tesouro estadunidense. Dessa forma, com o objetivo de amenizar os impactos sobre mercado cambial, resultante do grande volume de capital externo, os bancos centrais adotaram uma política de esterilização, que consistiu na operação nos mercados abertos, adquirindo moeda estrangeira dos bancos comerciais mediante troca por títulos da dívida pública. E ainda que esse fenômeno tenha sido parcialmente interrompido com a crise financeira mundial, após as medidas de socorro anunciadas pelo governo estadunidense ao sistema financeiro daquele país, houve uma nova onda de influxos de capital nas economias emergentes, em especial no Brasil (KALTERBRUNNER; PAINCEIRA, 2018).

A adoção desse tipo de política monetária, no entanto, trouxe uma série de impactos sobre as economias emergentes. A primeira delas está associada diretamente ao aumento da emissão de títulos da dívida pública, como no caso brasileiro. Embora tenha havido uma substituição da dívida em moeda estrangeira por dívida em moeda nacional, o problema da vulnerabilidade externa foi apenas amenizado, mas não completamente eliminado. Um dos motivos se deve ao fato de que permanece a dominância da aplicação financeira em títulos de curto prazo, mesmo no caso dos títulos do tesouro. Segundo os dados de 2014, o prazo médio de vencimento desses títulos era de 4 anos, e, em que pese, haja havido um pequeno alargamento dos prazos desde o início dos anos 2000, permanecia muito aquém do praticado por países como México, Rússia e África do Sul, cujas médias de vencimento naquele ano foram, respectivamente, de 8, 6 e 14 anos. Além disso, houve uma crescente financeirização das operações das empresas não financeiras, que passaram a operar nos mercados financeiros, e os próprios bancos comerciais realocaram seus portifólios para os títulos públicos e certificados no interbancário, reduzindo assim a oferta de crédito para investimentos produtivos, que possuem um prazo mais longo de maturação. Logo, a integração subordinada ao sistema financeiro mundial, com a abertura da conta financeira, alterou a própria lógica de atuação das empresas financeiras e não-financeiras no país (KALTERBRUNNER; PAINCEIRA, 2018).

Cria-se assim, um círculo vicioso, cujo custo para a esterilização do influxo de divisas externas implica um crescente endividamento público e deterioração fiscal, associado a um comprometimento da capacidade de acumulação de capital com restrição de oferta de crédito ao investimento produtivo, o que por sua vez limita o potencial de crescimento econômico do país. Tudo isso sem eliminar a vulnerabilidade externa inerente ao balanço de pagamentos. Ademais, na ocorrência de mudanças nas condições internacionais, que levem a uma saída de capital, o país tende a sofrer um duplo efeito de desvalorização da moeda nacional (com grande 
potencial inflacionário) e a autoridade monetária se vê obrigada a elevar as taxas de juros para evitar uma fuga em massa do capital externo, o que tende a retroalimentar os efeitos do endividamento, crise fiscal e baixo crescimento econômico (KALTERBRUNNER; PAINCEIRA, 2014; 2018).

Estudos econométricos recentes têm mostrado que os momentos de aumento da vulnerabilidade externa brasileira, promovido por diferentes canais, como o déficit em transações correntes e o crescente influxo de capitais estrangeiros - estes principalmente aplicados em ativos de curto prazo -, estão associados a curtos períodos de crescimento econômico no Brasil. No entanto, um processo de retroalimentação eleva posteriormente os riscos dos ativos financeiros no mercado interno, moldando a política monetária e funcionando como preditores de crises financeiras futuras, e, consequentemente, de seus impactos negativos sobre o nível de emprego e renda do país. Constatou-se uma causação mútua entre o índice de abertura financeira, taxa de juros, taxa de câmbio, saldo financeiro e dívida bruta externa do país (TIRYAKI, TEXEIRA; ARAÚJO, 2021; GOMES; ALBUQUERQUE; REZENDE, 2020). Esses resultados corroboram com a dinâmica subordinada da integração financeira e a consequente vulnerabilidade externa estrutural do Brasil, apontados por Kalterbrunner e Painaceira $(2014 ; 2018)$.

No entanto, não apenas a atuação da autoridade monetária, ao adotar uma estratégia defensiva de acumulação de reservas e de atração e retenção da capital financeiro colabora para a vulnerabilidade externa. A própria conduta das empresas não financeiras nacionais nos períodos de crescimento econômico gerou um crescente endividamento no setor privado, inclusive com captação de recursos no exterior a taxas de juros mais baixas, com o objetivo de aplicação em ativos financeiros no país, o que trouxe uma série de consequências para a retomada dos investimentos produtivos a partir de 2015. Em estudo com 239 empresas não financeiras de diversos setores de atividades, Ribas (2021) mostra que om desempenho econômico até 2010 induziu os empresários a assumirem maiores riscos, realizando investimentos produtivos mediante captação de recursos, implicando em acréscimo significativo no passivo de longo prazo. Para se ter a dimensão desse movimento, o índice de endividamento líquido, que em 2010 era de 52\% sobre o capital próprio, em média, atingiu o valor de $115 \%$ em 2015. Porém, a crise política e econômica no país de 2015 e 2016 obrigouas a rever suas posições. A queda nas receitas, em função do decrescimento da economia nesses anos, fez com que os saldos operacionais (Earnings before interest, taxes, depreciation and amortization - EBTIDA) fossem, em muitos casos, insuficientes para o cobrir as despesas 
financeiras. Isso as levou a fazer renegociação de dívidas, cortes nos investimentos, redução nas despesas operacionais e vendas de ativos para cobrir as necessidades de liquidez.

Por fim, cabe mencionar que, com o advento da pandemia da COVID-19 em 2020, houve uma alta expressiva da dívida pública do Brasil, assim como da maioria dos países em desenvolvimento. Por conta das medidas de isolamento social, houve uma forte retração da atividade econômica e, por conseguinte, da arrecadação do Estado. Somam-se as medidas de expansão dos gastos para em serviços de saúde e de assistência social e socorro econômico a empresas e trabalhadores. Tais ocorrências contribuíram para gerar elevado déficit primário, da ordem de R\$ 600 bilhões, em 2020. Combinado com outros vencimentos do governo, a necessidade de financiamento do setor público consolidado foi de quase $\mathrm{R} \$ 1,3$ trilhão, o que representou 9,5\% do PIB, um recorde histórico. Dessa forma, o país inicia a terceira década do milênio com um aprofundamento da dívida pública e, consequentemente, da vulnerabilidade externa estrutural (ELKHISHIN; MOHIELDIN, 2021; BRASIL, 2021; BCB, 2021).

Assim, em que pese as crises financeira de 2008 e da COVID-19 em 2020, nas últimas duas décadas o Brasil conseguiu reduzir a sua vulnerabilidade externa, mediante principalmente uma estratégia defensiva de acumulação de reservas internacionais pelo Banco Central e pela geração de superávits comerciais, especialmente no período de 2003 a 2008. No entanto, as políticas de controle de capital, principalmente as adotadas após 2010, não impediram os influxos de capital externo, principalmente os de curto prazo, nem tampouco tem sido capaz de evitar o que alguns economistas chamam de vulnerabilidade externa estrutural, associada principalmente à inserção subordinada no sistema financeiro internacional e a permanente ameaça de fuga de capitais, associada às condições externas e, portanto, independente dos fundamentos macroeconômicos da economia brasileira.

\section{Metodologia}

Para a análise da evolução da dívida externa brasileira de 2000 em diante, adotou-se, neste artigo, dois procedimentos metodológicos: o primeiro consistiu em uma pesquisa bibliográfica, e o segundo em um levantamento de dados secundários sobre o tema. Para o levantamento da literatura, foram pesquisados no Portal Periódicos da CAPES artigos científicos revisados por pares, utilizando-se como termos de busca as palavras-chave "dívida externa", "vulnerabilidade externa" e "Brasil", aplicando-se o operador booleano "OR" para as duas primeiras e o operador "AND” para a última. 
Restringiu-se os resultados para artigos publicados a partir de 2010, com o objetivo de selecionar trabalhos que já analisassem pelo menos a primeira década completa dos anos 2000. Após essa filtragem, permaneceram artigos que analisavam períodos anteriores ao dos objetivos do presente artigo. Estes foram mantidos, no sentido de dar suporte à contextualização da trajetória da dívida externa nas décadas anteriores. A seleção dos artigos para a revisão de literatura foi feita a partir da leitura dos títulos e resumos dos trabalhos resultantes da pesquisa, conforme a aderência das abordagens aos objetivos do presente estudo. A análise e discussão da literatura sobre a dívida externa brasileira ao longo das últimas duas décadas foram apresentadas seção anterior.

Com relação ao levantamento de dados secundários, foram utilizados dados, dos anos 2000 até 2021, apresentados em séries consolidadas, disponibilizadas no Sistema Gerenciador de Séries Temporais (SGS) do Banco Central do Brasil (2021). O SGS tem como objetivo consolidar e tornar disponíveis informações econômicas-financeiras e uniformizar documentos produzidos com base em séries temporais.

Afim de alcançar o objetivo do artigo, com o intuito de compreender a evolução da dívida externa brasileira a partir dos anos 2000, à luz dos fatos que ocorreram na economia brasileira e mundial, são explorados indicadores como: Dívida Líquida do Setor Público (DLSP), interna, externa, em níveis de governo federal e empresas estatais; Dívida Mobiliária Federal; Custo real da dívida não-monetária total; Posição de investimento internacional líquida; Taxa de juros SELIC; e Taxa de câmbio (R\$US\$). No Quadro 1 são apresentados os códigos para recuperação dos dados no Sistema Gerenciador de Séries Temporais (SGS) do Banco Central do Brasil (2021).

Quadro 1 - Códigos de recuperação de dados no Sistema Gerenciador de Séries Temporais (SGS)

\begin{tabular}{|c|l|}
\hline Código & \multicolumn{1}{c|}{ Nome da Série } \\
\hline 432 & Taxa de juros - SELIC Meta definida pelo Copom (\%) \\
\hline 3698 & Taxa de câmbio - Livre - Dólar americano (venda) - Média de período - mensal - u.m.c./US\$ \\
\hline 4154 & Dívida mobiliária (Saldos) - Títulos do Tesouro Nacional-posição em carteira - Total em mercado \\
\hline 4166 & Dívida mobiliária (Saldos) - Títulos do Banco Central-posição em carteira - Total em mercado \\
\hline 4503 & Dívida Líquida do Setor Público (\% PIB) - Total - Governo Federal e Banco Central - \% \\
\hline 4507 & Dívida Líquida do Setor Público (\% PIB) - Total - Governos estaduais - \% \\
\hline 4508 & Dívida Líquida do Setor Público (\% PIB) - Total - Governos municipais - \% \\
\hline 4509 & Dívida Líquida do Setor Público (\% PIB) - Total - Empresas estatais - \% \\
\hline 4513 & Dívida Líquida do Setor Público (\% PIB) - Total - Setor público consolidado - \% \\
\hline 4524 & Dívida Líquida do Setor Público (\% PIB) - Interna - Setor público consolidado \\
\hline 4535 & Dívida Líquida do Setor Público (\% PIB) - Externa - Setor público consolidado \\
\hline 10734 & Custo real da dívida não-monetária - Total (taxa) - \% a.m. \\
\hline 12506 & Posição internacional de investimentos (\% PIB) \\
\hline 22863 & Conta financeira - mensal - líquido - US\$ (milhões) \\
\hline 24010 & Posição de investimento internacional - Líquida (US\$ milhões) \\
\hline
\end{tabular}

Fonte: Elaborado pelos autores com base nos dados do Banco Central do Brasil (2021). 
Segundo o Banco Central do Brasil (2020), para o cálculo da DLSP se considera o setor público não-financeiro, ou seja, as administrações diretas das esferas federal, estadual e municipal, as administrações indiretas, o sistema público de previdência social e as empresas estatais não-financeiras, também das três esferas, e a empresa Itaipu Binacional. Vale destacar que a Petrobras e a Eletrobras são excluídas do cálculo, devido às características específicas destas empresas, que seguem regras de governança corporativa similares as de empresas privadas de capital aberto e com autonomia na captação de recursos nos mercados interno e externo. Fundos públicos, cuja fonte de recursos é constituída de contribuições fiscais ou parafiscais, e o Banco Central também compõem o setor público não-financeiro.

Cabe, ainda, sublinhar que a DLSP se refere ao total das obrigações do setor público não-financeiro, deduzido seus ativos financeiros junto a agentes privados e públicos financeiros e não-financeiros. Não considerados nesse conceito, os ativos e passivos financeiros do Banco Central, como as reservas internacionais e a base monetária. Já, ao se tratar da Dívida Líquida Externa, deve-se se ter em mente que este indicador é composto pelo total dos débitos contratuais desembolsados e ainda não quitados, emitidos ou contratados no exterior, enquanto a Dívida Líquida Interna respeita os mesmos critérios, mas em território nacional (BCB, 2020).

Antes de avançar para seção de resultados e discussão, deve-se apontar, dentre os indicadores analisados nesta pesquisa, a Dívida Mobiliária Federal como a maior parcela do endividamento público. De acordo com o Banco Central do Brasil (2018), isso se deve à composição deste indicador, que engloba os títulos que estão presentes no mercado, ou em carteira do Banco Central, emitidos tanto pelo Tesouro Nacional e quanto pelo Banco Central do Brasil. Na sequência, são apresentados e analisados os indicadores aqui elencados.

\section{Resultados e discussão}

A partir dos dados levantados das séries históricas do Banco Central do Brasil, apresenta-se nesta seção um panorama da evolução da dívida externa brasileira, sua composição e principais variáveis associadas. O objetivo é discutir os custos e a sustentabilidade da dívida externa, bem como a alteração ou manutenção da situação de vulnerabilidade externa do país.

Analisando os principais componentes da Dívida Líquida do Setor Público (DLSP) de dezembro de 2001 a junho de 2021, como percentual do PIB, tem-se as empresas estatais, os estados, municípios, governo federal e o Banco Central, cuja soma refere-se ao setor público consolidado. Durante toda a série, o governo federal e o Banco Central são responsáveis por, em média, $60 \%$ da dívida líquida pública brasileira, enquanto os estados correspondem a 30\%, 
os municípios a $4 \%$ e as empresas estatais a 5\% aproximadamente. Em média, a DLSP, referente ao setor público consolidado, corresponde a $44 \%$ do PIB, chegando ao seu valor máximo de $62,7 \%$ em dezembro de 2020.

Conforme observa-se no Gráfico 1, a DLSP em relação ao PIB brasileiro, tem um período inicial de ascensão, seguido de um período mais extenso de queda e, na sequência, um novo período de crescimento. O primeiro período se apresenta menos extenso em decorrência do período de análise determinado neste artigo, a partir dos anos 2000, e da disponibilidade de dados. Neste, a DLSP consolidada ascende até alcançar 62,45\% do PIB, em setembro de 2002, quando entra no período de decréscimo atingindo um mínimo de 30,01\% em janeiro de 2014 e volta a crescer até alcançar o pico de 62,7\% em dezembro de 2020.

Gráfico 1 - Dívida Líquida do Setor Público por níveis de governo, empresas estatais e consolidado, Brasil, de dezembro de 2001 a junho de 2021 (\% do PIB)

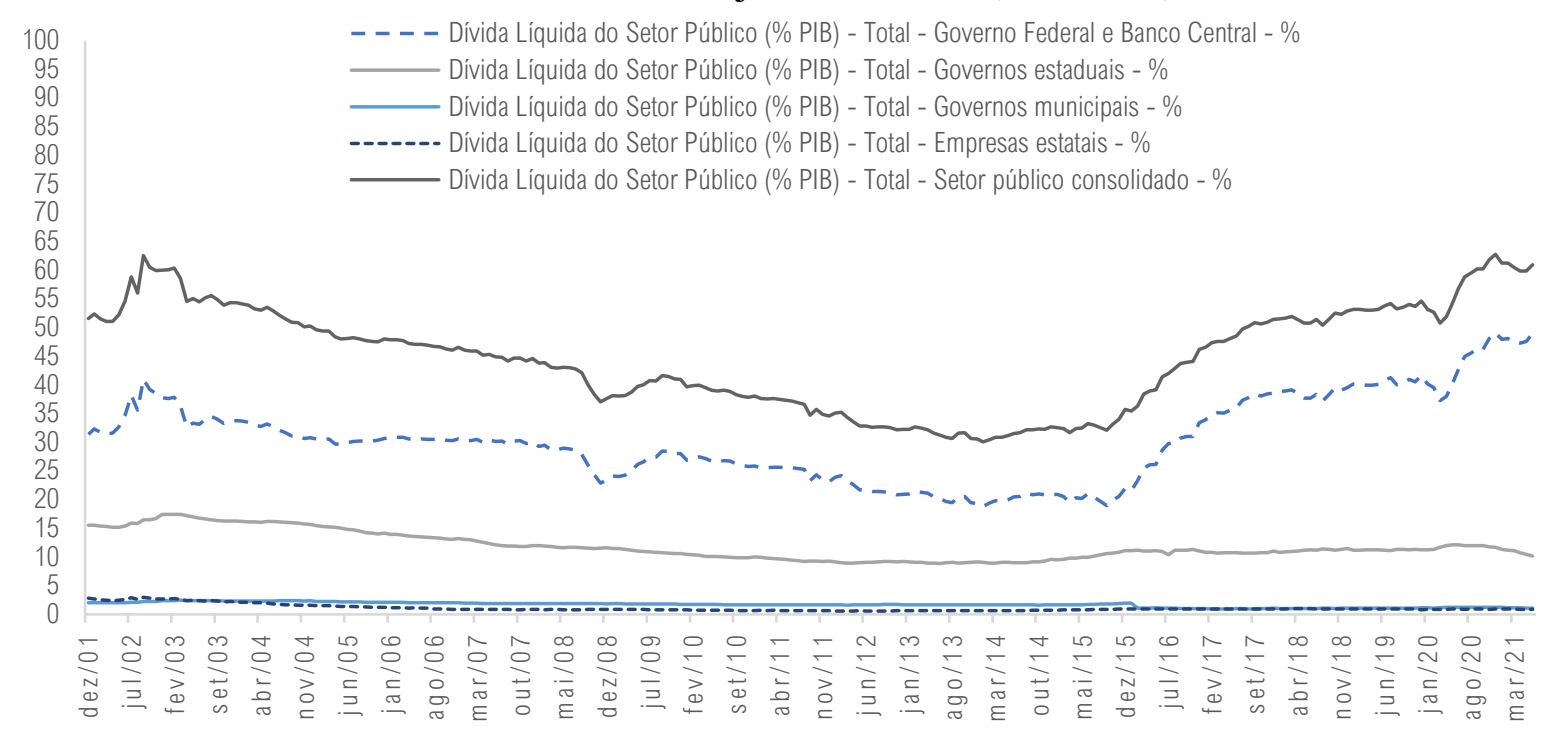

Fonte: Elaborado pelos autores com base nos dados do Banco Central do Brasil (2021).

Analisando-se mais a fundo tais períodos, observa-se que, antes dos anos 2000, até o ano de 2002 o Brasil encontrava-se ainda em período de estabilização, uma vez que a última fase do Plano Real entra em vigor apenas no ano de 1999, com a adoção do câmbio flutuante e a consolidação do regime fiscal com metas de superávit primário, que em conjunto ao Sistema de Metas de Inflação compõem o tripé macroeconômico brasileiro. A economia mundial se prepara para entrar em um ciclo expansionista de crescimento, principalmente decorrente do boom de commodities e efeito-China, permitindo elevado ingresso de divisas em países exportadores de produtos primários. 
É interessante notar que nas primeiras décadas do novo milênio, o governo brasileiro promoveu uma substituição da dívida pública externa pela interna, tornando-se inclusive um credor líquido a partir do segundo semestre de 2006, conforme demonstrado no Gráfico 2. Novamente, é possível observar o movimento de intenso crescimento da dívida pública federal interna a partir de 2015, como consequência dos crescentes déficits primários experimentados a partir de então. Isso resultou tanto da desaceleração da economia e, portanto, da arrecadação tributária, quanto das políticas de juros e da desvalorização cambial do período a elas associadas, que aumentaram os encargos financeiros do governo. Nem mesmo a emenda constitucional, que impôs limites à expansão das despesas primárias do governo federal, foi capaz de impedir o avanço do endividamento do Estado brasileiro, uma vez que as taxas de crescimento econômico observadas entre 2017 e 2019 (média de 1,5\% ao ano), foram insuficientes para recuperar o nível de atividade econômica de 2014. Ademais, a retração de 4\% em 2020 jogou uma pá de cal sobre a capacidade de equilíbrio fiscal a curto prazo.

Gráfico 2 - Dívida Líquida do Setor Público consolidado interna e externa, Brasil, de dezembro de 2001 a junho de 2021 (\% do PIB)

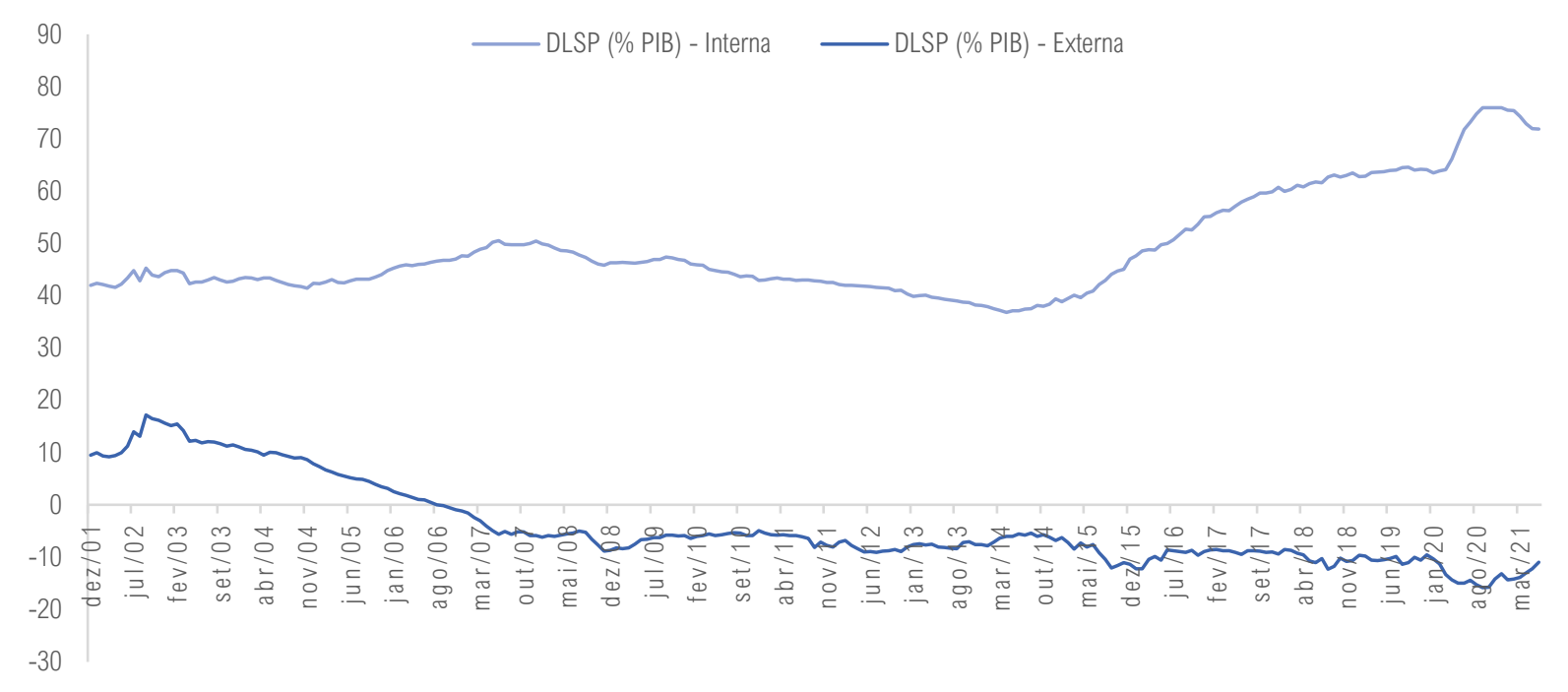

Fonte: Elaborado pelos autores com base nos dados do Banco Central do Brasil (2021).

O Gráfico 3 apresenta a evolução da dívida mobiliária do governo federal desde 2000 até junho de 2021, dívida entre os títulos emitidos pelo Tesouro Nacional e pelo Banco Central do Brasil. Com a aprovação da Lei de Responsabilidade Fiscal em 2000, ficou determinada a vedação da emissão de títulos pelo Banco Central por dois anos, após a promulgação da lei. Assim, a partir de novembro de 2006 o valor de títulos em carteira no mercado, para tais títulos, é zerado, com a expiração do prazo de recompra desses títulos, sendo as novas emissões 
cessadas já em 2002. A partir de então, apenas o Tesouro Nacional está autorizado a emissão de novos títulos da dívida pública.

Gráfico 3 - Dívida mobiliária (saldos), títulos do Tesouro Nacional e do Banco Central do Brasil, posição em carteira, total em mercado, Brasil, de janeiro de 2000 a junho de 2021 (R\$ milhões)

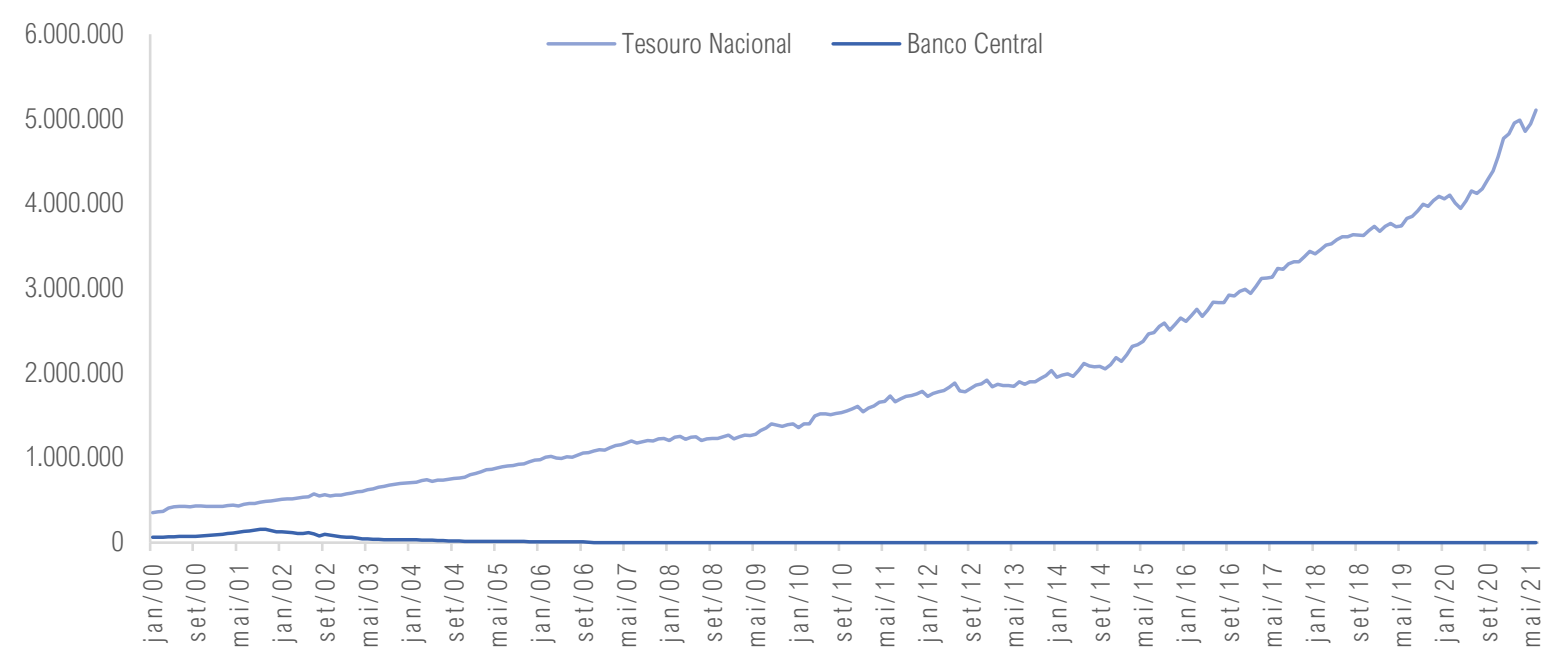

Fonte: Elaborado pelos autores com base nos dados do Banco Central do Brasil (2021).

O período de análise inicia com uma dívida mobiliaria do tesouro da ordem de R $\$ 400$ bilhões, cujo valor foi triplicado até o final de 2008, em torno de R \$ 1,2 trilhões. Até o final de 2014, esse número elevou-se para R \$ 2,1 trilhões, quando, a partir de então, registrou-se crescimento mais acelerado da dívida pública federal. Mesmo antes do advento da pandemia, a dívida praticamente havia dobrado ao final de 2019, quando atingiu o patamar de $\mathrm{R} \$ 4$ trilhões. Por conta da queda de arrecadação e aumento das despesas para enfrentamento da COVID-19, a dívida aumentou em mais $\mathrm{R} \$ 1$ trilhão, situando-se ao final do período em torno dos $\mathrm{R} \$ 5$ trilhões. Em que pese as dificuldades trazidas pela crise da pandemia, o país enfrentou uma importante crise política e econômica nos anos de 2015 e 2016, sendo que as contas públicas já vinham se deteriorando desde o final de 2013, quando já se registravam déficits primários. Portanto, o movimento de aceleração de emissão de títulos de dívida pública começou antes da pandemia, sendo que essa apenas agravou a situação fiscal do governo brasileiro.

Dando sequência na análise da crise vivenciada nos anos de 2015 e 2016, agora voltando a atenção para o custo real da dívida não-monetária total do Brasil, é possível observar no Gráfico 4 a ocorrência de um pico, em setembro de 2015, que atingiu patamares sem precedentes dentro do período analisado. Mesmo os maiores valores alcançados durante as oscilações ocorridas no início dos anos 2000, estes, ainda, se mostraram distantes do verificado em 2015. Destaca-se aqui a segunda maior elevação apresentada no Gráfico 4, a qual representa 
o mês de setembro de 2002 em que o indicador atingiu o marco de 4,53\%, ao passo que no mês de setembro de 2015 o mesmo alcançou a marca de $15,88 \%$.

Gráfico 4 - Custo real da dívida não-monetária total, Brasil, janeiro de 2001 a junho de 2021 (\% ao mês)

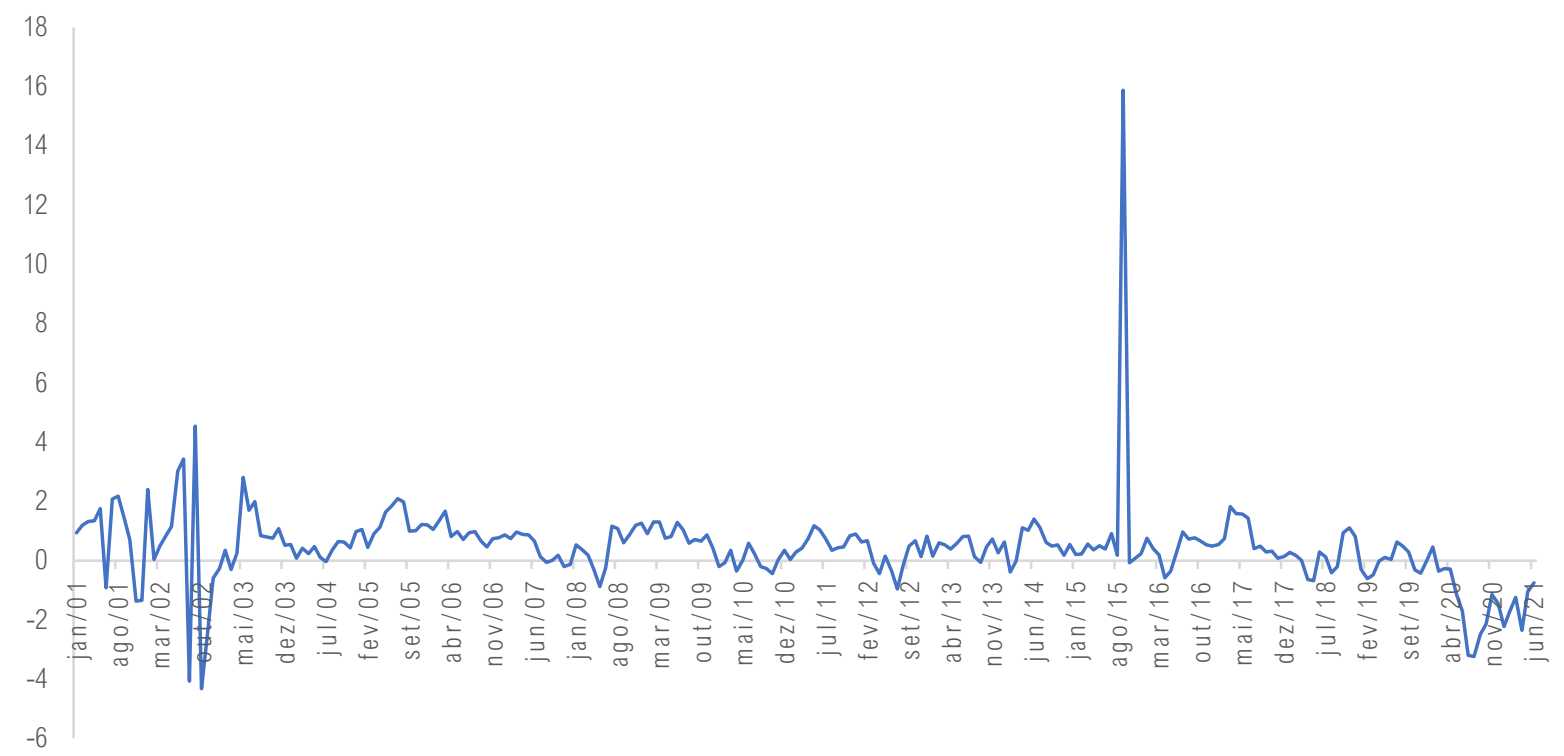

Fonte: Elaborado pelos autores com base nos dados do Banco Central do Brasil (2021).

Durante a crise, uma soma de fatores ressaltava as dificuldades econômicas e políticas no período, tais como a redução dos preços das commodities, elevação do desemprego, taxas de juros elevadas, entre outros fatores. Tal cenário levou a uma das agências de classificação de riscos dos países, a Standard \& Poor's (S\&P), a rebaixar a nota de crédito do Brasil, grau de investimento, de BBB- para BB+, no mês de agosto de 2015. Tal rebaixamento sinalizou um aumento no risco de o Brasil não quitar suas dívidas, trazendo insegurança aos investidores externos e, consequentemente, induzindo também à fuga de capital estrangeiro, elementos que conduzem ao encarecimento de financiamento externo (BRITO; COSTA, 2015).

A posição de investimento internacional líquida é uma medida de aproximação do endividamento externo líquido do país, dado pela diferença entre os valores de estoque e ativos e passivos em moeda estrangeira. Como demonstrado no Gráfico 5, no início do período de análise, embora os valores em dólares do endividamento externo fossem baixos (em torno de US\$ 270 bilhões), comparativamente ao que viria ser posteriormente, em termos relativos ao PIB do Brasil era bastante elevado, da ordem de 50\%. Ao longo dos anos seguintes, até 2008, observa-se um aumento no valor nominal da dívida externa brasileira, ao mesmo tempo que o bom desempenho econômico do período, em especial de 2003 e 2008, fez com que a relação da posição de investimento internacional líquida reduzisse para 17\% do PIB. De 2009 em 
diante, em que pese as oscilações trimestrais demonstrada no Gráfico 5, o nível de endividamento externo líquido do país se elevou significativamente. A posição média era negativa em torno dos US\$ 320 bilhões, enquanto no período de 2009 em diante a média mais do que dobrou, ficando ao redor de US\$ 660 bilhões.

Gráfico 5 - Posição de investimento internacional líquida, Brasil, do $3^{\circ}$ trimestre de 2001 ao $1^{\circ}$ trimestre de 2021 (US\$ milhões e \% do PIB)

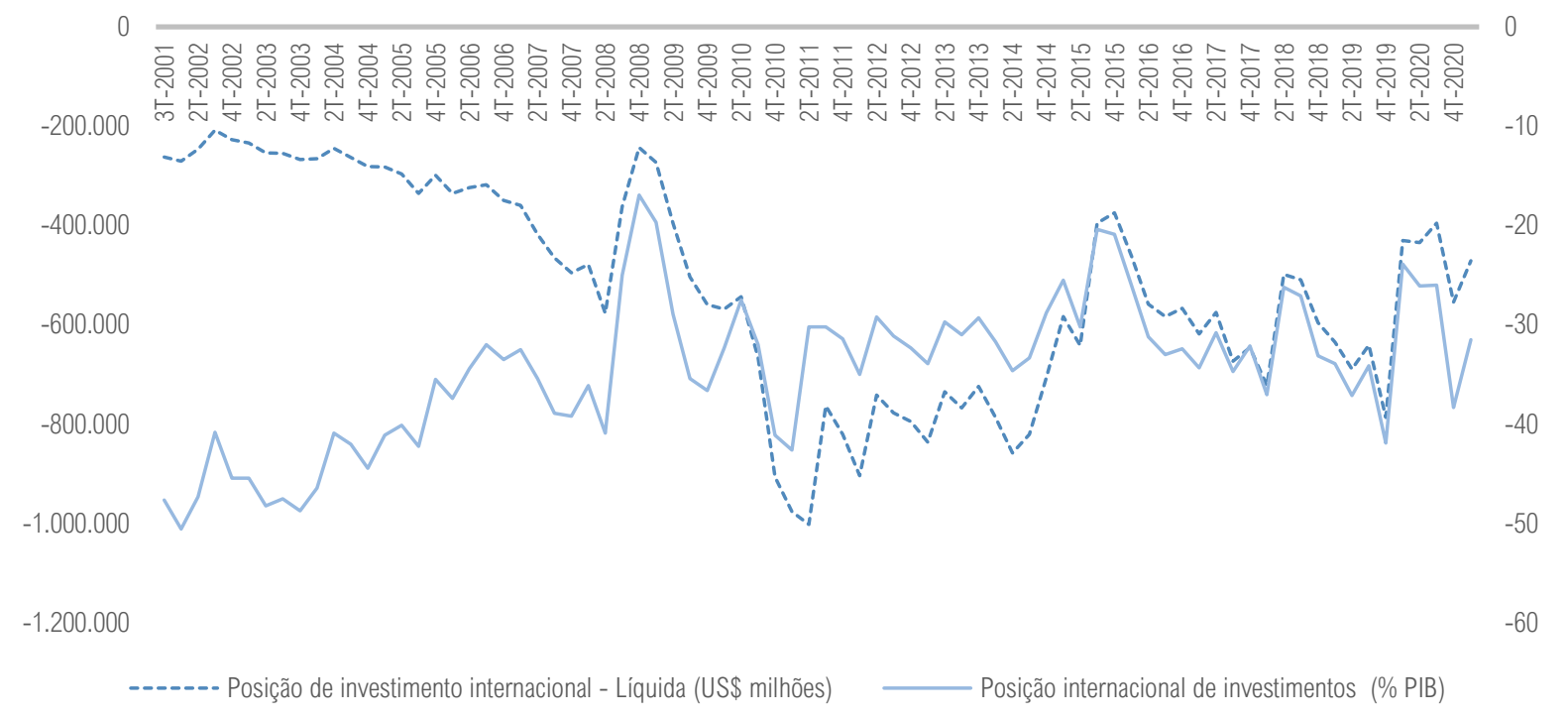

Fonte: Elaborado pelos autores com base nos dados do Banco Central do Brasil (2021).

O Gráfico 6 apresenta a evolução da taxa de juros meta da SELIC e da taxa de câmbio, entre 2001 e julho de 2021, com o objetivo de complementar a análise com essas variáveis fundamentais para a compreensão tanto da dívida pública e de seus encargos financeiros, quanto da atratividade do mercado financeiro nacional aos investidores estrangeiros e, consequentemente, da vulnerabilidade externa do país. As taxas de juros que iniciaram a série em torno dos $15 \%$ ao ano, atingiram um pico de $26,5 \%$ em meados de 2003 . A partir de então, ocorreu uma tendência de redução da taxa de juros, com algumas oscilações importantes ao longo do período, as quais merecem destaque. O primeiro período refere-se a agosto 2009 a abril de 2010, quando o Copom estabeleceu em 8,75\% ao ano a taxa de juros básica da economia brasileira, como resposta à crise financeira internacional de 2008 , que se fez sentir mais efetivamente no Brasil apenas no ano seguinte. O segundo período de tendência de baixa da SELIC ocorreu em 2012, quando atingiu uma taxa ainda mais baixa, de 7,25\% ao ano, entre outubro 2012 e março de 2013. Daí em diante, observa-se um movimento contrário, de elevação gradual e sucessiva, quando alcançou o patamar de 14,25\% em agosto 2015, mantendo-se assim até setembro 2016. Com a economia em queda a partir de então, em conjunção e com a redução 
das taxas de juros internacionais, um novo período de tendência de baixa veio a ocorrer, sendo os menores valores registrados entre agosto 2020 e fevereiro 2021, quando se estabeleceu em $2 \%$ ao ano a taxa SELIC.

Gráfico 6 - Taxa de juros SELIC meta (\%) e taxa de câmbio (R\$/US\$), média mensal, Brasil, de janeiro de 2001 a julho de 2021.

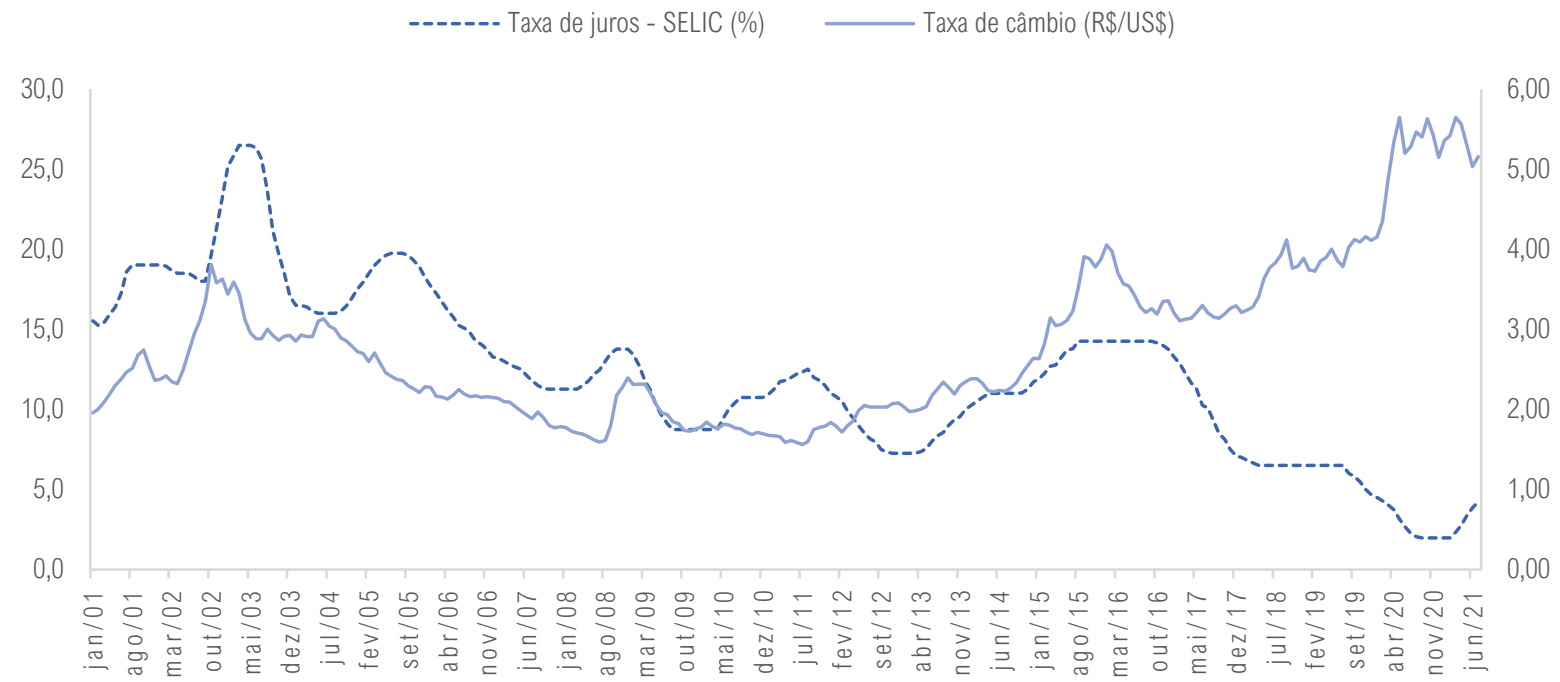

Fonte: Elaborado pelos autores com base nos dados do Banco Central do Brasil (2021).

Porém, desde março de 2021, há um viés de alta da taxa de juros, o que pode ser compreendido analisando-se esses dados em conjunto com os dos custos reais de emissão de títulos da dívida mobiliária federal, apresentados no Gráfico 4. A combinação das baixas taxas de juros com a aceleração da inflação, em 2020, representou um decréscimo significativo na rentabilidade real dos títulos públicos emitidos durante o período, o que implicou em rendimentos reais negativos. Por esse motivo, há uma pressão do mercado para a elevação da taxa de juros, além, é claro, do fato de que a inflação superou os limites das metas estabelecidas pelo Copom. Como o governo dispõe quase que exclusivamente da taxa de juros como instrumento de controle inflacionário, a tendência de alta pode ser interpretada como uma resposta natural aos fatores conjunturais da economia brasileira, ainda que seja questionável, em termos dos custos sociais, o uso deste instrumento de controle de preços em meio à pandemia, dado o elevado nível de desemprego em que se encontra a população brasileira ${ }^{2}$.

\footnotetext{
${ }^{2}$ Segundo o levantamento da Pesquisa Nacional por Amostra de Domicílios Contínua do IBGE, no $1^{\circ}$ trimestre de 2021, a taxa de desocupação foi de $14,6 \%$ da força de trabalho.
} 
Com relação à taxa de câmbio, há um movimento de desvalorização da moeda nacional entre 2001 e 2002, quando a relação com a moeda estadunidense passou da casa dos $R \$ 2$ por dólar, no início do período, para uma média de R \$3,60 no final do período. A partir de então, em função do crescimento das exportações (o chamado boom das commodities) e dos influxos de capitais ao país, a moeda brasileira passou a se apreciar, chegando à cotação mínima em julho de 2008, quando a taxa média do mês foi de R\$1,59 / 1 US\$. Com a crise financeira internacional, o real voltou a se desvalorizar, atingindo um pico em dezembro daquele mesmo ano, quando a cotação média foi de R \$2,39. No entanto, novamente observa-se a retomada da tendência de apreciação, que se estendeu até meados de 2013. A partir de então, a moeda nacional entrou em uma trajetória gradual e sucessiva de desvalorização frente ao dólar, com uma oscilação para baixo entre 2016 e 2017, porém em patamares ainda superiores aos observados nos períodos anteriores. A forte desvalorização cambial é explicada em grande medida pelo advento da pandemia da COVID-19 em 2020, que elevou a taxa de câmbio acima dos R \$ 5, embora essa tendência fosse anterior à emergência sanitária global. Assim, se até meados da segunda década do novo milênio a moeda brasileira mostrou-se apreciada, a partir de então ocorreu forte tendência de desvalorização do real, implicando em aumento dos riscos financeiros associados à dívida externa.

Observa-se, ainda, que a relação entre a taxa de juros e taxa de câmbio na economia brasileira, até 2009, tinha uma relação direta, isto é, ambas as variáveis seguiam a mesma tendência de alta e baixa. Após 2010, no entanto, o seu comportamento seguiu movimentos contrários $^{3}$. Isso significa que no primeiro período, além do controle inflacionário, a taxa de juros desempenhou um importante instrumento de atração de capital para resolução dos problemas de déficits em transações correntes, sendo relaxada em períodos de bonança, com entre 2003 e 2007, quando houve o boom das commodities, que proporcionou superávits em transações correntes. A combinação dos dois canais de influxo de divisas, transações correntes e conta financeira, geraram a forte apreciação do real nesses anos. Já no período seguinte, embora tenha havido um descolamento da tendência da taxa de juros e da taxa de câmbio, a primeira continuou a desempenhar papel fundamental na atração de capital, principalmente porque já em 2008 o saldo em transações correntes tornou-se negativo, sem haver reversão desse resultado a partir de então. Assim, a inversão da relação entre as variáveis se processou principalmente pelo comportamento da taxa de câmbio.

\footnotetext{
${ }^{3} \mathrm{O}$ coeficiente de correlação de Pearson foi de 0,768 para o período de janeiro de 2001 a dezembro de 2009, e de $-0,567$ entre janeiro de 2010 e junho de 2021, ambos estatisticamente significativo ao nível de 0,01 .
} 
O Gráfico 7 apresenta o saldo mensal da conta financeira do balanço de pagamentos do Brasil, para o período de 2001 a 2021. Como se pode observar, entre 2003 e 2007, quando o resultado líquido foi positivo, contribuindo com o ingresso de divisas no país, houve uma forte tendência de apreciação do real. No entanto, o acúmulo de saldos negativos de 2009 em diante resultou em movimento, já em 2011, de desvalorização do real, intensificando-se a partir de 2015. Os anos de 2016 e 2017 marcaram um período de reversão dessa tendência, que se bem não impediram uma saída líquida de capitais nesse período, pelo menos diminuiu consideravelmente o resultado comparativamente aos anos imediatamente anteriores. Porém, de 2018 em diante registraram-se novos e crescentes saldos negativos, representando uma saída líquida de capital estrangeiro, gerando como efeito uma nova onda de desvalorização da moeda brasileira. A relutância de intervenção, que resultaria em queima de reservas internacionais por parte do Banco Central, pode explicar, ao menos em parte, o movimento de desvalorização do real, integrando a estratégia de precaução para momentos de mudanças nas condições do mercado financeiro internacional que gerem uma forte reversão no fluxo de capitais, como apontado na literatura (KALTERBRUNNER; PAINCEIRA, 2014; 2018).

Gráfico 7 - Saldo mensal da conta financeira (US\$ milhões) e taxa de câmbio (R \$/US\$, média mensal), Brasil, janeiro de 2001 a junho de 2021

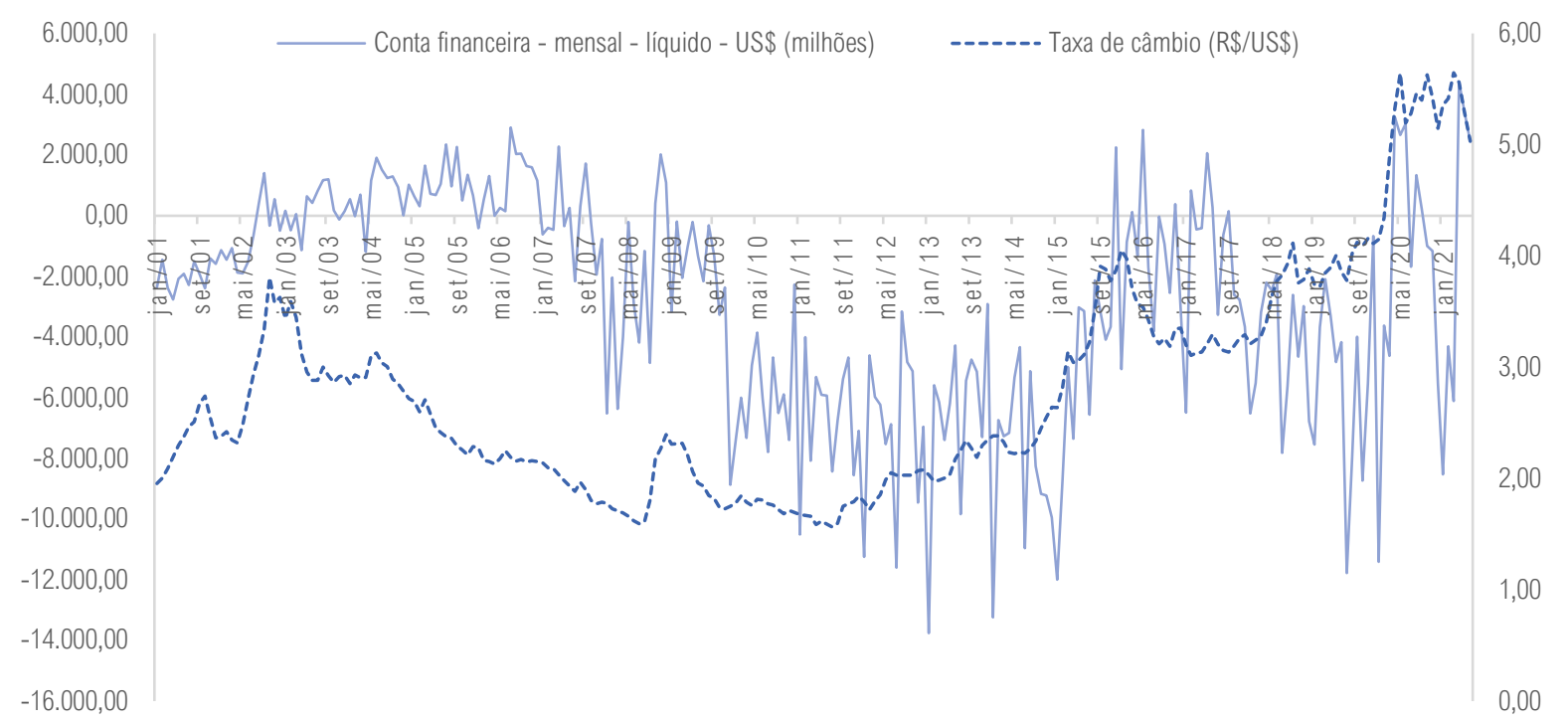

Fonte: Elaborado pelos autores com base nos dados do Banco Central do Brasil (2021).

Em síntese, as duas primeiras décadas do novo milênio foram marcadas por processos distintos com relação à dívida externa. Por um lado, até a crise de 2008, o país beneficiou-se de um grande influxo de divisas em moeda estrangeira, contribuindo, assim, para a redução da vulnerabilidade externa, comparativamente àquela observada nas décadas de 1980 e 1990, 
quando o governo teve de recorrer inúmeras vezes ao auxílio financeiro do FMI e outros órgãos multilaterais. Não obstante, nesse mesmo período, o país experimentou uma forte apreciação do real, o que reduziu sua competitividade internacional em outros setores da economia, em especial a indústria de transformação. Ademais, o custo de esterilização apresentou-se bastante elevado, havendo o predomínio da dívida pública interna de curto prazo - fato que se estende até os dias atuais. O segundo momento, principalmente a partir de 2010, marcou novo processo de aprofundamento da posição internacional de investimento devedora do país. Além disso, houve uma tendência gradual e sucessiva de desvalorização da moeda brasileira, explicada tanto pela reversão no saldo em transações correntes quanto pelo ingresso líquido de capital externo mais racionado na conta financeira, principalmente após 2015.

Deve-se ressaltar, por fim, os impactos da pandemia da COVID-19 sobre a dívida externa brasileira e as perspectivas que se colocam para o início da terceira década do milênio. A dívida pública do setor público aumentou expressivamente, em resposta à queda na arrecadação e ao aumento das despesas primárias para o enfrentamento da doença no país. Por outro lado, a taxa de juros atingiu a mínima histórica do período analisado, apontando que os custos de captação não foram tão elevados. Isso não significou que o governo brasileiro esteve em uma situação confortável, pois os déficits primários crônicos atingiram seu maior valor justamente em 2020. Diante desse quadro, permanecem para o momento seguinte os problemas de arrecadação e restrição aos investimentos públicos produtivos, dificultando ainda mais a retomada do crescimento, além da própria situação sanitária que não está ainda resolvida. Por conseguinte, implica na constante necessidade de refinanciamento da dívida mobiliária federal. Assim, a vulnerabilidade externa estrutural permanece, e mesmo sendo capaz de conservar um grande volume de reservas em moeda estrangeira, as perspectivas futuras impõe uma série de desafios e dúvidas sobre a sustentabilidade da dívida externa brasileira.

\section{Conclusão}

Neste artigo, buscou-se traçar um panorama da evolução da dívida externa brasileira nas primeiras décadas dos anos 2000. Os resultados da pesquisa bibliográfica e de levantamento de dados secundários mostraram que, por um lado, com a estratégia defensiva do Banco Central do Brasil e a alguns momentos de bonanças no comércio exterior (2003 a 2007), o país foi capaz de acumular um grande volume de reservas internacionais, o que contribuiu sobremaneira para a redução da vulnerabilidade externa. Some-se a isso a mudança na composição da dívida 
pública, tornando-se predominantemente interna, isto é, emitida em moeda nacional, o que representa um importante avanço quando comparada às observadas nas décadas de 1980 e 1990.

Já, por outro lado, após a crise de 2008, apesar de seguir acumulando reservas, ainda que a um ritmo menor, a posição internacional dos investimentos resultou em um aumento do passivo líquido externo em mais de duas vezes. Além disso, nem mesmo a política de esterilização foi capaz de evitar uma desvalorização da moeda nacional, explicada pelos déficits em transações correntes e pelo menor ingresso líquido de capital estrangeiro pela conta financeira, principalmente a partir de 2015. A segunda metade da década de 2010 foi marcada, assim, pelo agravamento da dívida externa pública e privada. E esse efeito foi intensificado em 2020 com o advento da pandemia de COVID-19.

A vulnerabilidade externa estrutural, como denominado por alguns economistas, parece não ter se alterado ao longo das duas décadas analisadas. Pelo contrário, ao término do período, a situação parece ter se agravado. A dominância financeira ainda impera sobre a política monetária no Brasil. A manutenção de taxas de juros atrativas ao capital externo tem o efeito de aumentar as despesas financeiras, principalmente do governo brasileiro, por meio da política defensiva de manutenção das reservas cambiais. Ademais, a deterioração físcal, resultante dos déficits primários crônicos, conduzem à necessidade recorrente de refinanciamento de dívida mobiliária federal.

Em períodos subsequentes, isso tende a gerar um efeito de retroalimentação, obrigando o Copom a aumentar o prêmio de risco dos títulos públicos, implicando em novos aumentos da taxa de juros. Como consequências, isso impõe a necessidade de redução das despesas primárias, como a já implementada no Brasil com a Emenda Constitucional no 95 de 2016 (que limitou o crescimento real das despesas primárias do governo federal). Por sua vez, isso limita a capacidade de investimento e prestação de serviços públicos, o que implica uma redução da demanda agregada, atuando como um dos fatores que limitam o crescimento econômico do país. Além disso, a integração financeira modificou a lógica dos investimentos das empresas financeiras e não financeiras, que alocaram seus recursos no mercado financeiro, especialmente em títulos de curto prazo. Isso traz como resultado a redução da oferta de crédito e a retração do investimento privado, sendo estes um segundo fator explicativo para o baixo crescimento econômico.

A preferência por títulos de curto prazo se traduz na necessidade permanente de atração de capital estrangeiro para equilibrar o balanço de pagamentos. Mesmo o saldo positivo na balança comercial, registrado de 2015 em diante, mostrou-se insuficiente para cobrir os déficits na balança de serviços. Assim, desde 2008 o país apresenta saldo negativo recorrente em 
transações correntes. Aliada à política defensiva de acumulação de reservas, o governo se vê preso em círculo vicioso de atração de capital estrangeiro. E, como apontado na literatura, a reversão súbita dos fluxos de capitais podem ocorrer independentemente dos fundamentos da economia doméstica, principalmente paras os países em desenvolvimento e que se integram de maneira subordinada ao sistema financeiro internacional, como é o caso do Brasil. Se há a ameaça de uma crise no balanço de pagamentos mesmo com bons fundamentos macroeconômicos, no caso de uma economia com baixo crescimento, com desvalorização cambial e deterioração fiscal, os riscos podem ser ainda maiores. Nesse sentido, a terceira década dos anos 2000 inicia impondo desafios às políticas econômicas e geram muitas dúvidas sobre a sustentabilidade da dívida externa brasileira.

\section{Referências}

BANCO CENTRAL DO BRASIL - BCB. Sistema Gerenciador de Séries Temporais - v2.1
https://www3.bcb.gov.br/sgspub/localizarseries/localizarSeries.do?method=prepararTelaLoca lizarSeries. Acesso em: 20 ago. 2021.

BANCO CENTRAL DO BRASIL - BCB. Dívida Líquida do Setor Público (\% PIB) - Total - Banco Central. 2020. Obtido em: https://dadosabertos.bcb.gov.br/dataset/4505-dividaliquida-do-setor-publico--pib---total---banco-central. Acesso em: 27 dez. 2020.

BANCO CENTRAL DO BRASIL - BCB. Manual de Estatísticas Fiscais. 2018. Obtido em: https://www.bcb.gov.br/ftp/infecon/Estatisticasfiscais.pdf. Acesso em: 20 ago. 2021.

BRASIL. Ministério da Economia. Secretaria Especial de Fazenda. Secretaria do Tesouro Nacional. Dívida Pública Federal: Relatório Anual 2020. Brasília: Secretaria do Tesouro Nacional, 2021. Obtido em: https://www.tesourotransparente.gov.br/publicacoes/relatorioanual-da-divida-rad/2020/114. Acesso em: 16 ago. 2021.

BRESSER-PEREIRA, L. C. Como sair do regime liberal de política econômica e da quaseestagnação desde 1990. Estudos Avançados, São Paulo, v. 31, n. 89, p. 7-22. jan.-abr. 2017. Obtido em: https://doi.org/10.1590/s0103-40142017.31890002 . Acesso em: 11 ago. 2021.

BRESSER-PEREIRA, L. C.; GONZALEZ, L.; LUCINDA, C. Crises financeiras nos anos 1990 e poupança externa. Nova Economia, v. 18, n. 3, p. 327-357, 2008. Obtido em: https://doi.org/10.1590/S0103-63512008000300001 . Acesso em: 10 ago. 2021.

BRITO, A.; COSTAS, R. Brasil Rebaixado: com perda de grau de investimento, dólar e juros podem ficar mais caros. BBC News. 2015. Obtido em: https://www.bbc.com/portuguese/noticias/2015/09/150909_brasil_rebaixamento_ab. Acesso em: 22 ago. 2021.

CUNHA, A. M.; PRATES, D. M.; BICHARA, J. S. La economía brasileña: su nuevo papel en el sistema financiero internacional. América Latina Hoy, n. 54, p. 167-197, 2010. Obtido em: https://www.redalyc.org/comocitar.oa?id=30813328008 . Acesso em: 11 ago. 2021. 
ELKHISHIN, S.; MOHIELDIN, M. External debt vulnerability in emerging markets and developing economies during the COVID-19 shock. Review of Economics and Political Science, v. 6, n. 1, p. 24-47, jun. 2021. Obtido em: https://www.emerald.com/insight/content/doi/10.1108/REPS-10-2020-0155/full/html. Acesso em: 20 ago. 2021.

GOMES, G. N.; ALBUQUERQUE, D. D. B.; REZENDE, L. P. F. Abertura financeira e endividamento externo dos países periféricos: uma análise do caso brasileiro. Economia Ensaios, v. 35, n. 1, jul./dez. 2020. Obtido em: https://doi.org/10.14393/REE-v35n1a202044159. Acesso em 22 ago. 2021.

INSTITUTO DE PESQUISA ECONÔMICA APLICADA - IPEA - IPEADATA. Metadados. 2021. Obtido em: http://www.ipeadata.gov.br/Default.aspx. Acesso em: 19 ago. 2021

KALTENBRUNNER, A.; PAINCEIRA, J. P. Developing countries' changing nature of financial integration and new forms of external vulnerability: the Brazilian experience. Cambridge Journal of Economics, v. 39, n. 5, p. 1281-1306, set. 2015. Obtido em: https://doi.org/10.1093/cje/beu038. Acesso em: 18 ago. 2021.

KALTENBRUNNER, A.; PAINCEIRA, J. P. Subordinated financial integration and financialisation in emerging capitalist economies: the Brazilian experience. New Political Economy, v. 23, n. 3, p. 290-313, 2018. Obtido em: https://doi.org/10.1080/13563467.2017.1349089. Acesso em: 20 ago. 2021.

MEDIALDEA, B. Brazil: an economy caught in a financial trap (1993-2003). Brazilian Journal of Political Economy, v. 33, n. 3, p. 427-445, jul./set. 2013. Obtido em: https://doi.org/10.1590/S0101-31572013000300004. Acesso em: 16 ago. 2021.

MUNHOZ, V. C. V. Vulnerabilidade externa e controle de capitais no Brasil: uma análise das inter-relações entre câmbio, fluxos de capitais, IOF, juros e risco-país. Nova Economia, v. 23, n. 2, p. 371-402, mai./ago. 2013. Obtido em: https://doi.org/10.1590/S010363512013000200005. Acesso em: 11 ago. 2021.

RIBAS, L. B. T. Ciclos financeiros e o financiamento da indústria no Brasil 2010-2019. 2021. 49 f. Monografia (Graduação) - Curso de Ciências Econômicas, Departamento de Economia, Universidade Federal do Paraná, Curitiba, 2021.

SALOMÃO, I. Do estrangulamento externo à moratória: a negociação brasileira com o FMI no governo Figueiredo (1979-1985). Revista de Economia Contemporânea, v. 20, n. 1, p. 5-27, jan.-abr. 2016. Obtido em: https://doi.org/10.1590/198055272011. Acesso em: 11 ago. 2021.

TIRYAKI, G. F.; TEIXEIRA, D. N.; ARAÚJO, V. F. Vulnerabilidade externa e os ciclos econômicos no Brasil pós-plano real. Economia Aplicada, v. 25, n.1, p. 115-156, 2021. Obtido em: http://dx.doi.org/10.11606/1980-5330/ea173917. Acesso em: 21 ago. 2021.

VAN NOIJE, P. Vulnerabilidade externa e composição da posição internacional de investimentos: Brasil 2001-2010, Revista de Economia Política, v. 34, n. 3, p. 471-484, jul./set. 2014. Obtido em: https://doi.org/10.1590/S0101-31572014000300007. Acesso em: 18 ago. 2021. 